\title{
Do institutional arrangements influence the speed of adoption of laser-land leveller technology in the irrigated farmlands of Punjab, Pakistan? A discrete-time duration analysis
}

\author{
Asjad Tariq Sheikh ${ }^{1}$, Amin Mugera ${ }^{1}$, Ram Pandit ${ }^{1}$, Michael Burton ${ }^{1}$, and Stephen Davies ${ }^{2}$ \\ ${ }^{1}$ The University of Western Australia \\ ${ }^{2}$ International Food Policy Research Institute
}

August 9, 2021

\begin{abstract}
Governments and international donors are actively promoting laser-land leveller (LLL) technology to produce environmental benefits (i.e., avoid soil salinity, minimize soil erosion risk, and groundwater security) that could lead to sustainable agricultural production and averting land degradation. We investigate the adoption process of laser-land leveller (LLL) technology in Punjab, Pakistan during the period 1985-2018 using survey data from 504 farming households. A discrete-time duration model is used to investigate factors that could influence the speed of adoption of LLL technology and an endogenous switching regression (ESR) model to evaluate its impact on groundwater usage. It is found that about $70 \%$ of the surveyed households had adopted the technology. The key determinants of the speed of adoption include strong legal land entitlements, farm size, and farm location along the watercourse. Information acquired through formal and informal sources and exposure to the technology potentially reduce adoption time. The adoption of LLL reduces groundwater use by about $23 \%$ in wheat crop. These results highlight the need for improved institutional arrangements such as extension services, technology exposure, and establishing legal property rights over land to enhance uptake of LLL technology.
\end{abstract}

Do institutional arrangements influence the speed of adoption of laser-land leveller technology in the irrigated farmlands of Punjab, Pakistan? A discrete-time duration analysis

Asjad Tariq Sheikha,11Corresponding author. E-mail addresses: asjadtariq.sheikh@research.uwa.edu.au, asjadtariqsheikh@gmail.com (Asjad Tariq Sheikh), amin.mugera@uwa.edu.au (Amin Mugera), ram.pandit@uwa.edu.au (Ram Pandit), michael.burton@uwa.edu.au (Michael Burton), S.Davies@cgiar.org (Stephen Davies), Amin Mugera ${ }^{\mathrm{a}, \mathrm{b}}$, Ram Pandit ${ }^{\mathrm{b}, \mathrm{c}}$, Michael Burton ${ }^{\mathrm{a}}$, b , Stephen Davies $^{\mathrm{d}}$

a The UWA Institute of Agriculture, The University of Western Australia, 35 Stirling Highway, Crawley, WA 6009, Australia.

b UWA School of Agriculture and Environment, University of Western Australia, 35 Stirling Highway, Crawley, WA 6009, Australia.

${ }^{c}$ Global Center for Food, Land and Water Resources, Research Faculty of Agriculture, Hokkaido University, Sapporo, Hokkaido 060-0815, Japan.

d International Food Policy Research Institute, Development Strategy and Governance (DSGD), 1201 Eye Street, NW, Washington, DC 20005, USA

\section{Acknowledgements}


We acknowledge the joint financial support for this research from the UWA International Research Training Program (RTP) scholarship and International Food Policy Research Institute (IFPRI) under contract No. 2019X103.UWA.

\section{ABSTRACT}

Governments and international donors are actively promoting laser-land leveller (LLL) technology to produce environmental benefits (i.e., avoid soil salinity, minimize soil erosion risk, and groundwater security) that could lead to sustainable agricultural production and averting land degradation. We investigate the adoption process of laser-land leveller (LLL) technology in Punjab, Pakistan during the period 1985-2018 using survey data from 504 farming households. A discrete-time duration model is used to investigate factors that could influence the speed of adoption of LLL technology and an endogenous switching regression (ESR) model to evaluate its impact on groundwater usage. It is found that about $70 \%$ of the surveyed households had adopted the technology. The key determinants of the speed of adoption include strong legal land entitlements, farm size, and farm location along the watercourse. Information acquired through formal and informal sources and exposure to the technology potentially reduce adoption time. The adoption of LLL reduces groundwater use by about $23 \%$ in wheat crop. These results highlight the need for improved institutional arrangements such as extension services, technology exposure, and establishing legal property rights over land to enhance uptake of LLL technology.

Keywords: Laser Land Leveller, Land management, Discrete-time duration model, Endogenous switching regression, Propensity score matching

\section{Hosted file}

adoption of LLL_20210730_Final.docx available at https://authorea.com/users/429756/articles/ 533382-do-institutional-arrangements-influence-the-speed-of-adoption-of-laser-landleveller-technology-in-the-irrigated-farmlands-of-punjab-pakistan-a-discrete-timeduration-analysis 